\section{Apontamentos introdutórios sobre o desafio decolonial para as teologias latino-americanas*}

\author{
Carlos Alberto Motta Cunha**
}

RECIBIDO: 25-05-17. APROBADO: 20-09-17

Resumo: A desvinculação epistêmica proposta pela decolonialidade revela não só a colonização do saber, como a do poder e do ser também, pelas culturas dominantes. Uma forma de saber construído nos espaços liminares, nas fronteiras da diferença colonial, na perspectiva do subalterno, está deslocando e absorvendo as formas hegemônicas do conhecimento e empoderando novos movimentos de emancipação. A teologia cristã é afetada por tal contexto e interpelada ao exercício libertador de remexer a sua base e repensar as suas categorias a partir de outros lugares de enunciaçáo. O nosso objetivo é mostrar os passos necessários para uma formação teológica decolonial.

Palavras-chave: Desafio decolonial; teologias latino-americanas; teologia da libertação; Paulo Freire.
Introductory Notes on the Decolonial Challenge for Latin American Theologies

Aвsтract: The epistemic decoupling proposed by decoloniality reveals not only the colonization of knowledge, but also of power and of the being, by the dominant cultures. A form of knowledge built in liminal spaces, at the frontiers of the colonial difference is-from the point of view of the subaltern-displacing and absorbing the hegemonic forms of knowledge, as well as empowering new movements of emancipation. Christian theology is affected by such a context and challenged by the liberating exercise of tinkering with its own basis and rethinking its categories from other places of enunciation. Our purpose is to show the necessary steps to acquire a decolonial theological formation.

Keywords: Decolonial challenge; Latin American Theologies; Liberation Theology; Paulo Freire.

\section{PARA CITAR ESTE ARTÍCULO:}

Cunha, Carlos Alberto Motta. "Apontamentos introdutórios sobre o desafio decolonial para as teologias latino-americanas". Theologica Xaveriana 185 (2018): 1-20. https://doi.org/10.11144/javeriana. tx68-185.aiddtl

\footnotetext{
* Artigo como parte da pesquisa de pós-doutorado em Teologia realizada nos anos 2016-2017 na Faculdade Jesuíta de Filosofia e Teologia com apoio do PNPD-CAPES, do Ministério da Educação do Brasil, sob orientação do professor Dr. Pe. Geraldo Luis De Mori, S. J.

** Doutor em Teologia e pós-doutorando em Teologia pela Faculdade Jesuíta de Filosofia e Teologia, FAJE, em Belo Horizonte (MG), Brasil, onde atua como professor colaborador. OrCID: 0000-00021981-7120. Correio eletrônico: carlosamc04@gmail.com/
} 


\section{Introdução}

Quando se fala em "pós-colonialismo", duas noçôes estão presentes e correlacionadas. A primeira, diz respeito ao tempo histórico posterior aos processos de decolonizaçáo do chamado "terceiro mundo", a partir da metade do século XX. Tal ideia refere-se à independência, libertaçáo e emancipaçáo das sociedades exploradas pelo imperialismo e neocolonialismo. A segunda noção, associada a esta, diz respeito ao conjunto de contribuições teóricas oriundas principalmente dos estudos literários e culturais, que a partir dos anos 1980 ganharam evidência em algumas universidades dos Estados Unidos e da Inglaterra ${ }^{1}$.

Próximo aos estudos pós-estruturais, desconstrutivistas e pós-modernos, o pós-colonialismo propõe uma epistemologia crítica às concepçóes dominantes da modernidade. Marcado pela relação antagônica entre colonizado e colonizador, o movimento pós-colonial assume a opção pelo colonizado reagindo às situaçóes de opressão diversas, definidas a partir de fronteiras de gênero, étnicas ou raciais. O tema dessa relação atravessou várias áreas do saber. Do ensaísmo literário ao marxismo latinoamericano, passando pela teoria da dependência à filosofia e à teologia da libertação, nota-se que o problema da colonialidade esteve fortemente presente no pensamento político e socioeconômico do sul global. Mesmo que não linear, disciplinado e articulado, o argumento pós-colonial em toda sua amplitude histórica, temporal, geográfica e disciplinar percebeu a diferença colonial e intercedeu pelo colonizado.

A amplitude do movimento pós-colonial abraça no seu interior teorias e pensamentos diversos em busca de novos lugares de enunciação. O Grupo Modernidade/Colonialidade é um deles. Formado por intelectuais latino-americanos e americanistas, o Grupo investiga novas formas de pensar e de atuar politicamente diante da nova ordem econômica-política transnacional e o seu impacto cultural. A mudança na redefinição das esferas política e cultural latino-americanas levou vários intelectuais da região a revisar epistemologias previamente estabelecidas nas ciências sociais e humanidades. Inspirado principalmente no pensamento do sociólogo peruano Aníbal Quijano, o Grupo afirma que a modernidade oculta a colonialidade, isto é, atrás da "modernidade”, do discurso da salvação, do progresso, da modernização e do bem comum está a lógica colonial encoberta impondo o controle, a dominação e a exploração².

A colonialidade europeia e/ou estadunidense se reproduz em uma tripla dimensão: a do poder, do saber e do ser impondo "a continuidade das formas coloniais de

\footnotetext{
${ }^{1}$ Ballestrin, "América Latina e o giro decolonial”, 90-91.

${ }^{2}$ Palermo e Quintero (coords.), Aníbal Quijano: textos de fundación, 64-70.
} 
dominação após o fim das administrações coloniais, produzidas pelas culturas coloniais e pelas estruturas do sistema-mundo capitalista moderno/colonial"3. É preciso um "giro decolonial" proposto pelos estudos decoloniais como resistência teórica e prática, política e epistemológica, à lógica da modernidade/colonialidade.

Reconhecida a colonialidade, feita a crítica a partir da sua perspectiva, o próximo passo indispensável é o desprendimiento, segundo Quijano, ou delink, conforme Mignolo: mudança epistemológica. Foi no campo epistemológico que a retórica da modernidade ganhou força por produzir e reproduzir discursos e narrativas que justificam a colonialidade. A decolonialidade abre espaço para uma razão subalterna lutando para afirmação dos saberes historicamente subalternizados. O desvinculamento epistêmico não significa abandono ou ignorância do que já foi institucionalizado por todo o planeta, mas um "aprender a desaprender" ". O processo de decolonização revela o "totalitarismo da cumplicidade da retórica da modernidade e a lógica da colonialidade, a fim de abrir espaço para a possibilidade [...] de 'outro mundo', em que muitos mundos coexistirão"s.

Tendo o movimento do pós-colonialismo como pano de fundo e o pensamento decolonial como instrumento teórico/prático contestador, o presente artigo almeja pensar a interpelação de tal postura epistêmica sobre a formação teológica na América Latina e, especificamente, no Brasil. Como o pensamento decolonial interpela a teologia cristâ? Quais são os horizontes de possibilidade para um quefazer teológico numa perspectiva decolonial? Estas são algumas das perguntas que a nossa pesquisa busca responder de forma inconclusa.

A inconclusividade marca a nossa caminhada. $\mathrm{O}$ artigo está dividido em quatro partes assinaladas por verbos no gerúndio: desinstalando, decolonizando, libertando e formando. O tempo verbal gerúndio na língua portuguesa indica normalmente um processo em curso ou prolongado. Essa é a nossa ideia, isto é, apontar para a ação contínua de uma teologia de fronteira lutando contra processos hegemônicos de uniformização em prol de manter o seu vigor libertador. Desinstalar-se dos próprios lugares para criticar a si mesma e possibilitar novos encontros parece ser fundamental no processo de decolonizaçáo das amarras que impossibilitam a teologia cristá avançar para além dos seus espaços. Em linhas gerais, é esse o caminho das três primeiras partes.

Na quarta parte, o educador brasileiro Paulo Freire nos ajuda na empreitada. A sua pedagogia libertadora, anterior ao pensamento decolonial, mas que já carrega

${ }^{3}$ Grosfoguel, "Para decolonizar os estudos de economia política e os estudos pós-coloniais: transmodernidade, pensamento de fronteira e colonialidade global”, 126.

${ }^{4}$ Mignolo, "Desobediência epistêmica: a opção descolonial e o significado de identidade em política", 305.

${ }^{5}$ Idem, La idea de América Latina. La herida colonial y la opción decolonial, 469. 
o espírito decolonizador, é inspiração para uma formação teológica decolonial. E não só isso, a ação cultural proposta pelo pensamento freireano desperta a teologia e as igrejas, como instrumentos sociais, no processo de empoderamento questionando e se libertando das estruturas de dominação. Faremos uma breve introdução à leitura bíblica decolonial como ponto de partida para esse processo emancipador.

\section{Desinstalando a teologia}

A teologia cristã hodierna carece de instrumentos teóricos capazes de fazer avançá-la para além do universo da comunidade de fé e transitar por outros espaços. Isso não significa negar a sua origem eclesial, mas não se pode restringir-se somente a esse lugar. No mundo plural de hoje, a teologia estritamente fechada, isto é, privada e monoconfessional, está condenada a não ser ouvida e a não ser sequer entendida pela sociedade. Diante da complexidade das culturas contemporâneas, tal teologia se mostra incapaz de dirigir-se a ela. Há uma necessidade de ela avançar para além das suas referências provincianas com o objetivo de dirigir sua palavra ao mundo todo. Caso contrário, "quem quiser se colocar fora desse reconhecimento se automarginaliza, não será atendido, e provavelmente também não será entendido”.

Nos últimos anos, o termo "teologia pública" surge nos cenários internacional e nacional com a pretensão de resgatar a tarefa pública da teologia, marcando posição diante dos problemas que envolvem o humano e a criação . Sem ser uniforme, monolítica e de um único significado sobre ela que seja autoritativo, a designação "teologia pública", beirando a redundância verbal, remete para a necessidade de pensar a natureza do seu conhecimento no esforço de esclarecer a sua importância, "indissociavelmente dos poderes que a ele conferem legitimidade e legalidade".

A diversidade religiosa e cultural da contemporaneidade anseia por uma teologia de fronteira capaz de discernir os "sinais dos tempos" (Mt 16,3) e dizer a sua própria palavra de modo novo e pertinente. A contemporaneidade reclama a construção de uma teologia não só consciente da pluralidade cultural e religiosa, mas capaz de abraçar dentro de seu horizonte as experiências sócio-religiosas do conjunto da humanidade. Esta tarefa de reescrever a teologia, e/ou de recriar seu conteúdo, implica um novo tipo de teólogo, com um novo tipo de consciência e postura diante da atualidade. Parece-nos desafiador propor que a teologia cristã se desinstale dos seus

${ }^{6}$ Vigil, Por uma teologia planetária, 26.

${ }^{7}$ Jacobsen, "Modelos de teologia pública”, 68.

${ }^{8}$ Passos, "A construção do conhecimento legítimo: percursos e desafios para a teologia pública no Brasil", 58. 
próprios espaços e se ressignifique a partir do exercício de autoavaliação e encontro com outras possibilidades.

O ser humano habita espaços determinados. Alguém já disse que a nossa cabeça está onde os nossos pés estão, isto é, os ambientes que frequentamos determinam, de certo modo, o nosso modo de pensar. Lugares familiares, religiosos, culturais, políticos, do conhecimento e outros formam a visão de mundo do sujeito que ali se constrói. Desinstalar-se dos próprios lugares, passa a ser na contemporaneidade, uma necessidade para aqueles que almejam um olhar que conjugue o micro e o macro da realidade. $\mathrm{O}$ nosso tempo é marcado pela complexidade de mundos que se entrecruzam trazendo à tona o dinamismo da vida e do humano. Sair dos espaços de origem e ousar pisar novos lugares não só permite ver com mais propriedade os limites e as contribuições dos próprios recintos como também possibilita a abertura para horizontes mais amplos?

Para que o trânsito entre lugares aconteça não é necessário que o sujeito abra mão da sua própria identidade. Aliás, um movimento entre espaços pressupóe um enraizamento, um senso de pertença aguçado, capaz de manter o ser humano em condiçóes de reconhecer o valor da alteridade e não se perder nos ambientes alheios. O diálogo e encontro que emergem da circulação entre os espaços não é fruto de concordismos e muito menos de relativismos, mas é o resultado da divergência de olhares que se complementam e da crítica madura e responsável.

A teologia cristá que almeja ter o que dizer aos dilemas do mundo atual é interpelada a se desinstalar dos seus próprios ambientes e trilhar novos caminhos. Chamamos de "teologia de fronteira" a intelecção da fé que se atreve a ampliar o seu horizonte de percepção por meio do contato com outras realidades ${ }^{10}$. A tendência de uma teologia igrejeira, provinciana, preocupada somente com as necessidades das igrejas, para uma teologia do mundo, sem abrir máo da sua morada, voltada para o encontro dialogal com outras áreas do conhecimento, com outras culturas, com outras pessoas e com outros saberes parece ser um caminho necessário para uma teologia cristã relevante.

Quando a teologia avança para além da sua zona de conforto ela rompe com a comodidade própria de quem se acostumou com o seu próprio mundinho. Trilhar outros lugares e ser confrontados por eles permite à teologia enxergar os seus próprios limites, corrigi-los e avançar rumo a uma participação ativa nos dilemas atuais. Como é saudável e relevante o discurso de fé de um teólogo desinstalado que colhe para a sua reflexáo os frutos de quem transita entre e através dos vários lugares.

\footnotetext{
${ }^{9}$ Cfr. o recente trabalho de Tamayo, Teologías del Sur: el giro descolonizador (2017).

${ }^{10}$ Cunha, “Teologia pública e o conceito de 'fronteira' no pensamento de Paul Tillich”, 116.
} 
A teologia cristã não precisa deixar de ser teologia e nem cristã para trilhar espaços diversos. Pelo contrário, quanto mais transita, mais segura de si mesma fica e porque tem identidade formada pode dizer a sua própria palavra ao mundo. Nesse nosso tempo marcado por agudos problemas, sinais de esperança e profundas contradições, a busca por uma intelecção da fé consistente se intensifica e percorre caminhos múltiplos. De cursos de teologia para "leigos", nas comunidades de fé, a faculdades de teologia, com pesquisas de nível stricto sensu, a formação teológica vai propiciando articulaçóes entre a tarefa pública da teologia e a construção da sociedade civil, oferendo às igrejas orientaçôes necessárias para a sua atuação além dos seus próprios ambientes.

\section{Decolonizando a teologia}

Os constantes movimentos de empoderamento de hoje assinalam o anseio por grupos de pessoas que exigem reconhecimento. O nosso tempo é marcado por "perguntas fortes e respostas fracas" ${ }^{11}$. Não basta, na atualidade, ser tolerante. A tolerância aparece como resposta fraca diante do acolhimento das diferenças. O reconhecimento, mais do que a tolerância, surge como resposta forte às sociedades plurais da contemporaneidade. Reconhecer é dar sentido e legitimidade ao outro. É um ato libertador. Já o tolerar, por mais que se admitem maneiras de pensar, agir e de sentir diferentes das nossas, não é capaz de conferir ao diferente a dignidade que lhe é merecido.

O momento atual, de profundas transformaçôes e com enormes desafios, interpela os saberes em busca de "respostas fortes" a questionamentos desconcertantes, provenientes de novas realidades, as quais é impossível ignorar ou colocar-se à margem. O quefazer teológico não escapa desta demanda. Novas interpelaçóes se impõem à teologia obrigando-a a um alargamento do seu conceito e de sua tarefa. Urge a necessidade de reconstruçấo de uma epistemologia teológica capaz de dialogar com o mundo atual de modo relevante e libertador.

Os conteúdos revelados da fé são transculturais, recebidos segundo o modo de seus receptores e transmitidos por sujeitos contextualizados. Náo existe teologia não inculturada, ela é produto humano, com resultados provisórios em formulaçôes aproximativas à fé cristã, consequência dos limites dos instrumentos de investigação. A teologia é produto humano, limitado pelas contingências culturais, o que não reduz em nada a revelação. Pelo contrário, além de livrá-la do reducionismo ideológico, possibilita condiçôes de abertura à nova compreensão do mundo e dos seres humanos,

\footnotetext{
${ }^{11}$ Santos, "Os direitos humanos na zona de contacto entre globalizações rivais", 24.
} 
o que "faz da teologia um discurso 'sobre' o Absoluto e não um discurso absoluto" A teologia, como uma atividade humana, reflexiva e falível, não se imagina de modo exaustivo ou oniabrangente. Os aspectos da vida mudam com o tempo, de modo que o ser humano deve voltar e pensar, de tempos em tempos, quais são as implicações, para o presente, das verdades teológicas percebidas no passado. "Os resultados da teologia são sempre provisórios, pois são formulaçôes sempre aproximativas da fé cristấ, consequência dos limites dos instrumentos de investigação" ${ }^{13}$. A teologia é inconclusa porque está sempre a caminho num processo constante de reestruturação diante do dinamismo da vida.

Movimentos de empoderamento são impulsionados pelas suspeitas do estado "natural" das coisas. Com tais movimentos, novos questionamentos surgem indagando sobre a veracidade e o sentido de posturas hegemônicas. A teologia cristã não escapa desta suspeita. Antes, pelo contrário, absorve as perguntas do tempo presente na busca por uma educação teológica focada na necessidade de tratar sobre novos temas numa perspectiva salvadora/libertadora.

As teorias decolonias ajudam nessa tarefa. Elas propiciam um momento oportuno para analisar o próprio método da teologia latino-americana e a sua relação com a libertação. O movimento da decolonialidade é tanto um discurso crítico que traz para o primeiro plano o lado colonial do sistema mundial moderno e a colonialidade do poder embutida na própria modernidade, quanto um discurso que altera a proporção entre os locais geohistóricos e a produção de conhecimentos. A relação entre a localização geográfica e localização epistêmica assinalam como essa relação é estabelecida pela diferença colonial e colonialidade do poder. Não existe modernidade sem colonialidade ${ }^{14}$.

O pensamento decolonial demanda o fazer decolonial, isto é, um giro com a pretensão de substituir a geopolítica de Estado de conhecimento de seu fundamento na história imperial do Ocidente dos últimos cinco séculos, pela geopolítica de Estado de pessoas, línguas, religiōes, conceitos políticos e econômicos, subjetividades etc., que foram negadas ${ }^{15}$. Tal comprometimento propóe: (1) Desvelar a lógica da colonialidade e da reprodução da matriz colonial do poder; e (2) desconectar-se dos efeitos totalitários das subjetividades e categorias de pensamento ocidentais ${ }^{16}$.

\footnotetext{
${ }^{12}$ Brighenti, “Teologia e pluralismo religioso", 87.

${ }^{13}$ Idem, "Natureza, lugar e função da teologia: inovações da teologia latino-americana", 173.

${ }^{14}$ Quijano, "Colonialidad del poder y clasificación social”, 342-386.

${ }^{15}$ Dussel, "Descolonização epistemológica da teologia”, 19-30.

${ }^{16}$ Grosfoguel, “Para decolonizar os estudos de economia política e os estudos pós-coloniais”, 115-147.
} 
É preciso repensar a metodologia teológica tal como ela é feita nos centros do saber. Não é possível decolonizar a teologia sem identificar a teologia hegemônica por meio de uma reflexão crítica que intenta problematizar as dinâmicas socioculturais e geopolíticas contemporâneas na América Latina trazendo à tona a ontologia colonial. Caso contrário, a teologia corre o risco de ser instrumento de colonização.

Não se trata de negar o labor teológico feito nos centros do conhecimento. A negação precipitada da história do pensamento teológico beira as raias da ingenuidade intelectual. O pensamento decolonial aponta para a emergência de novos lugares de enunciação, uma "gnose liminar" que é expressão de uma razão subalterna lutando para afirmação dos saberes historicamente subalternizados. Essa gnose ou pensamento liminar é uma reflexão crítica sobre a produção do conhecimento e implica na sua redistribuição geopolítica até então pautada na colonização epistêmica e na subalternização de todas as formas de saberes, povos e culturas que não estivessem pautadas nos cânones da ciência eurocêntrica ${ }^{17}$.

Portanto, o deslocamento do lócus de enunciação dos centros do sistema moderno-colonial para suas margens, para as fronteiras das diferentes histórias locais não significa negar a importância da teologia ocidental hegemônica. Não se trata também de um relativismo cultural e epistêmico. Esses projetos não são universais e abstratos, mas circunscritos nos limites das diferenças coloniais específicas na formação do sistema-mundo moderno colonial. O problema consiste na teologia uniforme e uniformizadora, que não reconhece o diferente e é incapaz de pensar a partir de novas realidades.

\section{Libertando a teologia}

No início de 1970, Juan Luis Segundo já falava sobre a libertação da teologia das amarras colonizadoras no seu famoso livro Libertação da teologia. Esta libertação acontece quando a teologia se submete ao exercício libertador das suas ideias e métodos arcaicos próprios de uma intelecção da fé encerrada em sua torre de marfim. Remexer a base da teologia cristã, a partir das demandas do mundo contemporâneo e exigir que ela tenha uma palavra/ação efetiva, parece ser fundamental para uma teologia que anseia ser contextual.

Para isto, Segundo propõe o exercício de libertação: primeiro, a suspeita ideológica; segundo, aplicação da suspeita a toda superestrutura e à teologia; terceiro, nova maneira de experimentar a realidade teológica levando à suspeita exegética e, quarto, uma nova hermenêutica. Quatro momentos importantes de um círculo hermenêutico

\footnotetext{
${ }^{17}$ Mignolo, Histórias locais/Projetos globais: colonialidade, saberes subalternos epensamento liminar, 409-418.
} 
para uma teologia liberta e libertadora que passa pela "suspeita sistemática de que tanto a teologia vivida, como sua expressão acadêmica, têm sido desviadas para finalidades massivas, com sua correspondente distorção de conteúdos" ${ }^{18}$.

A teologia genuína é essencialmente decolonizadora. Ela é crítica de si mesma: ...só isso pode fazer dela um discurso não-ingênuo, consciente de si, em plena posse de seus instrumentos conceituais. Mas não apenas a esse aspecto, de caráter epistemológico, fazemos alusão ao falar da teologia como reflexão crítica. Referimo-nos também a uma atitude lúcida e crítica com relação aos condicionamentos econômicos e socioculturais da vida e da reflexão da comunidade cristá: não os considerar é enganar-se e enganar os outros. ${ }^{19}$

A teologia decolonial é desafiada a refundar o seu processo educacional com a necessidade de ouvir atentamente o clamor dos marginalizados problematizando as dinâmicas socioculturais e geopolíticas contemporâneas e deixando transparecer os processos de colonização. A epistemologia que daí emerge questiona os mecanismos hegemônicos e, ao mesmo tempo, dá voz à pluralidade de construçóes do conhecimento. A consciência da articulação entre os saberes nos espaços fronteiriços é condição de possibilidade para novas relaçóes nos vários níveis da realidade e para uma nova elaboração teológica.

A partir da crítica decolonial, três disposiçóes são necessárias para uma formação teológica na América Latina: (1) Profunda honestidade com respeito a situação de crise da matriz colonial que persiste em nossas instituiçóes e discursos. (2) Sensibilidade para discernir a pluralidade de vozes e formas alternativas de ser, fazer, dizer e pensar e como isso se articula com novas epistemologias. (3) Ação intencional que logre mudanças profundas para que os espaços tradicionais de educação teológica empoderem as vozes emergentes ${ }^{20}$.

A intelecção da fé, consciente dos espaços liminares por meio das diferenças coloniais e na perspectiva do subalterno, se lança ao desafio de construir um projeto de vida cristã pragmático. Tal perspectiva não se limita ao contexto das comunidades de fé e nem das teologias. Esse projeto social vai mais além dos limites das igrejas e da teologia produzida nos centros do saber. Chamado de "cristianismo da libertação", por ser um conceito mais amplo que teologia ou que Igreja, inclui tanto a cultura religiosa e a rede social, quanto a fé e a prática engajado na salvação comunitária e

\footnotetext{
${ }^{18}$ Segundo, Libertação da teologia, 252.

${ }^{19}$ Gutiérrez, Teologia da libertação: perspectivas, 68.

${ }^{20}$ Panotto, "Decolonizar la educación teológica", 7.
} 
pública em que os empobrecidos "já não são objeto de piedade ou caridade e sim, como os escravos hebraicos, agentes de sua própria emancipação" ${ }^{21}$.

A teologia encontra a fonte de seu conhecimento não só nas palavras da fé, mas também, e iluminada por elas, na prática da fé, que atualiza e encarna a Palavra no aqui e agora da vida concreta. Teologia que não leva em consideração à práxis, isto é, a capacidade de transformação da realidade humana não empenha o seu papel libertador. Mais do que refletir, é preciso mudar. Teologia digna brota de um compromisso humano, pré-teológico, para mudar e melhorar o mundo. Ela é atitude crítica iluminada pelas demandas do contexto. "A comunidade cristã professa uma fé que age pela caridade. Ela é - deve ser- caridade eficaz, ação, compromisso com o serviço. A teologia vem depois, é ato segundo" ${ }^{22}$.

Cabe ao quefazer teológico se perguntar se está ou não comprometido com a prática libertadora; se está aberto ou não a decolonizar-se e transformar-se radicalmente, entendendo a necessidade e os mecanismos do ser, do fazer e do saber dos povos subalternos. Há uma constataçáo em alguns segmentos teológicos da atualidade de que "as exigências do contexto exigem uma transformação intercultural e interreligiosa do fazer teológico em nossas cabeças, nosso hábito de trabalho, nosso modo de ensinar, nossas instituições" ${ }^{23}$.

Desde os anos de 1960 emerge teologias pluralistas e progressistas focadas em projetos libertadores:

Para as quais Deus se revela no sofrimento humano injusto, nas experiências de vida de todas as vítimas de dominação, opressão ou discriminação e nas lutas de resistência que elas promovem. Como consequência, prestar testemunho a este Deus significa denunciar este sofrimento e lutar contra ele. Tanto a revelação quanto a redenção, ou antes, libertação, têm lugar neste mundo, sob a forma de uma luta por outro mundo possível. Aqui reside a possibilidade de ligar o retorno de Deus a um humanismo trans-moderno concreto. ${ }^{24}$

A teologia da libertação, como teologia progressista, tem um papel fundamental na tarefa pública da teologia cristá. As mediaçóes sócio-analíticas criadas por ela trouxeram para o interior da reflexão teológica as questóes sociais emergentes e, ao mesmo tempo, possibilitaram a discussão teológica para além do espaço eclesial. A publicidade social da teologia na América Latina fê-la não somente mais visível mundo afora, mas também mais confiável como reflexão socialmente comprometida e academicamente

\footnotetext{
${ }^{21}$ Löwy, O que é cristianismo da libertação? Religiāo e política na América Latina, 74-92.

${ }^{22}$ Gutiérrez, Teologia da libertação, 68.

${ }^{23}$ Fornet-Betancourt, "La interculturalidad a prueba", 55.

${ }^{24}$ Santos, Se Deus fosse um ativista dos direitos humanos, 112-113.
} 
séria, fato que pode ser verificado na sua intensa produção bibliográfica. As igrejas que assumiram a teologia da libertação e o desafio da opção preferencial pelos pobres foram "laboratórios de investigação e produção teológicas responsáveis por lançarem a reflexão teológica para a sociedade" 25 .

A teologia da libertação lançou os fundamentos de um fazer teológico contextual, especialmente em vista de suas dimensôes econômicas, políticas e sociais. Inspirada no projeto de Reino de Deus, ela vem agregando sucessivamente todos os tipos de temas, assuntos e referências teológicas com intuito de transformar a sociedade. Da "teologia da libertação" para "teologias da libertação", a teologia pública libertadora mantém o seu caráter progressista e militante.

\section{Formação teológica decolonial}

Há a necessidade de articular a teologia com a construção da sociedade civil, dando orientação às igrejas, quanto à sua atuação além do seu ambiente, em diálogo constante com as esferas da sociedade, a partir de uma perspectiva de fé a ser oferecida como contribuição nos espaços públicos. $\mathrm{O}$ encontro entre projetos sociais libertadores e as teologias progressistas parece ser um caminho viável para o desenvolvimento de práticas verdadeiramente interculturais e eficazmente emancipadoras:

O resultado será uma ecologia de concepçóes de dignidade humana, algumas seculares, outras religiosas, produto daquilo a que noutro lugar chamei hermenêutica diatópica, um exercício de interpretação transformadora, orientada para a prática social e política, entre os topoi dos direitos humanos e os topoi da revelação e libertação das teologias políticas progressistas. ${ }^{26}$

As teologias progressistas estão social e culturalmente contextualizadas e com a importante missão de aprofundar a consciência crítica de pessoas e grupos sociais concretos, subalternizados por mecanismos imbuídos em reforçar relaçóes injustas e desiguais de poder. Faz-se necessário a participação efetiva das comunidades de fé nutridas por teologias conscientes e engajadas na luta por uma sociedade justa.

\section{Pedagogia decolonial de Paulo Freire}

No contexto da América Latina e especificamente no Brasil, a pedagogia do oprimido de Paulo Freire emerge como um instrumento decolonizador importante no processo de açóes culturais focadas na libertaçáo. O trabalho de Freire junto aos

\footnotetext{
${ }^{25}$ Passos, "A construção do conhecimento legítimo", 71.

${ }^{26}$ Santos, Se Deus fosse um ativista dos direitos humanos, 113.
} 
empobrecidos tem um reconhecimento mundial. O educador chegou a ser secretário de Educação da cidade de São Paulo (1988), na gestão de Luiza Erundina, e responsável por projetos pedagógicos de alfabetização e conscientização política desenvolvidos junto aos grupos subalternizados, a saber: o Movimento de Educação de Base, MEB, e o Movimento de Alfabetização, MOVA.

O legado de Freire é inquestionável. "As suas obras e o seu testemunho de vida refletem a grandeza deste nordestino que mudou os rumos da educação no Brasil e virou referência mundial de um processo educacional libertador" ${ }^{27}$.

A pedagogia libertadora de Freire é profundamente marcada por um conceito de libertação consciente da relação entre colonizador/colonizado e disposto ao rompimento com todas as amarras que impossibilitam a humanização plena:

O que nos parece indiscutível é que, se pretendemos a libertação dos homens não podemos começar por aliená-los ou mantê-los alienados. A libertação autêntica, que é a humanização em processo, não é uma coisa que se deposita nos homens. Não é uma palavra a mais, oca, mitificante. É práxis, que implica a ação e a reflexão dos homens sobre o mundo para transformá-lo. ${ }^{28}$

A formação proposta por Freire demanda uma "revolução", isto é, a consciente participação política do povo. A pedagogia crítica contribui para trazer à consciência do sujeito os processos ideológicos de opressão. Feito isso, o passo seguinte é o quefazer libertador. O projeto freireano é uma pedagogia da consciência produtora de libertação que adquire força nos programas político-culturais como açóes culturais para a liberdade. A partir desse arcabouço teórico, "o tema da libertação emerge como processo de humanização que tem na práxis o ethos da ação e reflexão do ser humano integral sobre o mundo para transformá-lo" 29 .

Chama atenção na pedagogia de Freire como o conceito de libertação emerge marcado por elementos do processo de conscientização diluídos na articulação entre fé e política. Por exemplo, no livro Ação cultural para a liberdade (1981), Freire, influenciado pela teologia da libertaçáo, acentua a importância das igrejas no processo de libertação. Evidentemente que, para tal feito, assumir uma teologia decolonial é condição essencial para que as comunidades de fé tenham respaldo bíblico-teológico crítico e disposiçáo ao empoderamento.

No capítulo O papel educativo das igrejas na América Latina, do livro supracitado, Paulo Freire faz apontamentos para uma formação cristã disposta à decolonização.

\footnotetext{
${ }^{27}$ Cunha, Hermenêutica biblica libertadora: encontros entre católicos e pentecostais, 197.

${ }^{28}$ Freire, Pedagogia do oprimido, 77.

${ }^{29}$ Cunha, Hermenêutica biblica libertadora, 197.
} 
Mesmo que o texto não seja específico sobre o labor teológico, as suas intuições cooperam para a elaboraçáo de uma teologia em perspectiva decolonial no contexto de igrejas politicamente dedicadas em transformaçôes culturais.

Em primeiro lugar, Freire diz que as igrejas não são entidades abstratas, mas constituídas por pessoas historicamente situadas na concretude da realidade humana. Portanto, não há como se manter numa posição de neutralidade diante das demandas políticas, sociais, culturais e outras. "Não se pode lavar as mãos em face de inconciliáveis, a não ser tornando-se o partido dos fortes" ${ }^{30}$. A dita "neutralidade", na verdade, é uma posição política em favor dos dominantes ou colonizadores.

Segundo, a práxis, ação cristã refletida, é fruto de um compromisso histórico. É por meio dela que as consciências se transformam numa lógica espiral crescente entre prática e teoria. $\mathrm{O}$ agir das igrejas reflete o seu labor teológico. Como se faz teologia: dos dados da fé para a realidade contextual ou, ao contrário, da realidade vivida para buscar nos dados revelados a diretriz da práxis cristãe Primeiro, a vida concreta e, só depois, as formulaçóes teóricas. "A reflexão só é verdadeira quando nos remete ao concreto sobre o qual a exercemos" ${ }^{31}$.

Terceiro, Freire lembra a dimensão profética das igrejas. "Ser revolucionário significa estar contra a opressão, contra a exploração, em favor da libertação das classes oprimidas, em termos concretos e não em termos idealistas" ${ }^{32}$. Igrejas de teologias progressistas tem o que dizer/fazer diante às inquietaçóes de uma geração ansiosa por transformação social. Ao assumir o compromisso com os oprimidos, e ser um com eles, as comunidades de fé testemunham publicamente o espírito contestador da tradição cristã perante os poderes constituídos.

Só os oprimidos, como classe social proibida de dizer sua palavra, podem vir a ser utópicos, proféticos e esperançosos, na medida em que seu futuro não é a mera repetição deformada de seu presente. Seu futuro é a concretização de sua libertação, sem a qual não podem ser. Só eles podem denunciar a "ordem" que os esmaga e, na práxis da transformação desta "ordem", anunciar um mundo novo a ser refeito constantemente. ${ }^{33}$

A Igreja profética de uma teologia profética não cai na armadilha do discurso vazio descompromissado com a realidade concreta das pessoas. Ela é libertadora, profética, utópica e esperançosa quando há compasso entre o discurso da salvação

\footnotetext{
${ }^{30}$ Freire, Ação cultural para a liberdade, 85.

${ }^{31}$ Ibíd., 88.

${ }^{32}$ Ibíd., 91.

${ }^{33}$ Ibíd.
} 
aliado às obras de libertação. Não há como chegar à transcendência sem passar pela mundanidade. "Não há humanização sem libertação, assim como não há libertação sem a transformação revolucionária da sociedade de classes, em que a humanização é inviável" ${ }^{34}$.

E, por fim, Paulo Freire retoma o processo de classificação colonial feito pela Europa e pelos Estados Unidos. A modernidade é colonialidade quando rotulam povos, culturas e raças como instrumento classificatório de dominação. A ideia do "terceiro mundo", assim como a "América Latina", é categorização ideológica, política e não geográfica.

O terceiro mundo, em última análise, é o mundo do silêncio, da opressão, da dependência, da exploração, da violência exercida pelas classes dominantes sobre as classes oprimidas [...]. Os europeus, de sociedades tecnologizadas, e os norte-americanos não têm necessidade de vir à América Latina para tornar-se proféticos. Basta buscar a periferia de suas grandes cidades, sem "inocência" ou "esperteza”, e ai encontrarão suficiente estímulo para repensar-se. Encontrarão, em face deles, uma das expressóes particulares de seu terceiro mundo. Assim, então, podem compreender a inquietação com que se traduz a posição profética na América Latina. ${ }^{35}$

\section{Horizontes para uma teologia decolonial}

Uma teologia decolonial ainda está para ser elaborada. Há muitas teologias da libertação que assumiram as críticas do pós-colonialismo, mas, de forma incipiente, existe pouca reflexão teológica acolhendo o instrumental teórico do pensamento decolonial. Para esta tarefa o que não falta é horizontes de desafios.

Juan José Tamayo, por exemplo, aponta alguns destes horizontes com a proposta de um novo paradigma teológico para outro mundo ser possível. Os horizontes intercultural, inter-religioso, hermenêutico, feminista, ecológico, ético-prático, simbólico, inter-disciplinar são alguns dos campos férteis para a elaboração de uma teologia decolonial ${ }^{36}$. Além dos propostos, poderíamos falar sobre outros horizontes como: do indígena, da sexualidade, dos direitos humanos, do pensamento complexo e transdisciplinar, dos grupos Lésbicas, Gays, Bissexuais, Travestis, Transexuais e Transgêneros, LGBTs, da migração e mobilidade humana e tantos outros em que a teologia deve se posicionar com uma palavra própria e pertinente.

\footnotetext{
${ }^{34}$ Ibíd., 98.

${ }^{35}$ Ibíd., 102.

${ }^{36}$ Tamayo, “Teologia para outro mundo é possível”, 444-450.
} 
A sensibilidade frente às exigências do tempo presente é fundamental para uma intelecção da fé disposta a ouvir o clamor dos subalternizados e se perguntar, sinceramente, se está aberta a reformar-se radicalmente a ponto de assumir, sem pudor, a luta do colonizado.

Por motivos óbvios de delimitação e de coerência, nos limitaremos a uma pequena reflexão decolonial sobre a fonte primária da teologia: a Bíblia, sua leitura, interpretação e aplicação. A Bíblia ocupa uma importância fundamental na tradição cristã e sem a sua leitura decolonial seria impossível propor teologias decoloniais. Os mais de vinte cinco anos de trabalho com a formaçáo bíblico-teológica junto às igrejas, aos cursos bíblicos, aos seminários e faculdades de teologia, tanto na tradição católica quanto na protestante, no Brasil, nos dão uma dimensão do modo como o fiel, leigo ou não, acolhe os textos sagrados.

No primeiro momento, a indistinção entre Bíblia e Palavra de Deus aparece como um problema comum. Para muitos cristãos as palavras são sinônimos, o que não é verdade. Enquanto Bíblia, coletânea de livros, realça o processo redacional dos textos, a Palavra de Deus vai para além do texto lido e tradicionado na e pela comunidade eclesial. A Bíblia é o acolhimento da revelação por homens e mulheres situados historicamente e limitados pelas particularidades históricas. Já a Palavra de Deus envolve uma amplitude mais profunda:

A Palavra é, antes de tudo, o princípio da automanifestação divina no próprio fundamento do ser [...] tem caráter de logos. A Palavra é o meio de criação, a palavra espiritual dinâmica que medeia entre o mistério silencioso do abismo do ser e a plenitude dos seres concretos, individualizados, auto-relacionados [...]. A Palavra é a manifestação da vida divina na história da revelação. É a Palavra recebida por todos aqueles que estáo em uma correlaçáo revelatória [...]. A Palavra é a manifestação da vida divina na revelação final. A Palavra é um dos nomes para designar Jesus como o Cristo [...]. O termo Palavra é aplicado ao documento da revelação final e de sua preparaçáo especial, isto é, a Bíblia [...]. Chama-se de Palavra a mensagem da igreja tal como esta a proclama em sua pregaçáo e seu ensino.... ${ }^{37}$

A não observação do aspecto histórico da revelação bíblica desemboca numa leitura fundamentalista em que a bíblia perde a sua natureza teândrica. Para o fundamentalista, o texto bíblico foi ditado palavra por palavra pelo Espírito de Deus e, neste processo, o autor humano é considerado mero copista que registrou a mensagem divina. Com esta mentalidade, os textos sagrados já disseram toda a sua palavra e, portanto, são textos fechados e impossibilitados de novas releituras.

${ }^{37}$ Tillich, Teologia sistemática, 169. 
Já na formação teológica decolonial, o reconhecimento da Bíblia como um livro de tensão entre particularidade histórica, lado humano, e, relevância eterna, parte divina, acolhe possibilidades de leituras orientadas a partir dos subalternizados, que buscam na Sagrada Escritura respostas para situaçôes de colonização, luta e libertação. Mais do que um interesse pelo "mundo do autor", a leitura bíblica decolonial foca a situação vivida pelo marginalizado e como a sua realidade ilumina a leitura dos textos fazendo brotar forças mobilizadoras para transformar a sociedade. "Portanto, a interpretação da Bíblia não pode ser neutra; precisa deixar surgir o entendimento que só se descobre quando seu texto é lido em solidariedade com a comunidade dos pobres e oprimidos" 38 .

A libertação do discurso religioso fundamentalista, implicando a passagem da teologia como mera exegese de textos para uma teologia hermenêutica em busca de sentido, deu um novo alento a interculturalidade da fé. O encontro dessa noção de hermenêutica com a teologia possibilita uma nova compreensão e um novo dinamismo da intelecção da fé. Não mais vistas como ciências autônomas e de regras rígidas, a teologia e a hermenêutica se fundem no esforço por atualizar o sentido da Palavra para hoje. Compreender teologia como hermenêutica é tomar a sério a historicidade da verdade, inclusive da verdade revelada, e também tomar a sério o humano, como sujeito interpretante. A teologia é atividade hermenêutica, uma vez que ela é "interpretação da significação atual do acontecimento Jesus Cristo a partir das diversas linguagens da fé suscitadas por ele, sem que nenhuma delas possa ser absolutizada, nem mesmo a do Novo Testamento" ${ }^{39}$.

A leitura bíblica decolonial questiona as leituras hegemônicas feitas pelas igrejas para manter um sistema de colonização. A apropriação indevida da Bíblia feita pelo homem, branco, heterossexual, europeu e do sistema patriarcal reduziu a compreensão dos textos bíblicos ao mundo do colonizador e impediu a sua apropriação pelos marginalizados ${ }^{40}$. Os conhecimentos produzidos no campo das ciências bíblicas por esse segmento da sociedade são politicamente engendrados, vinculando os conceitos e as formulaçóes teóricas e interpretativas às relaçóes sociais de poder vividas e experimentadas. É preciso criticar tais mecanismos para a produção de conhecimento e de significados nas formulações metodológicas que levam em consideração o campo religioso latino-americano marcado pela luta e por interesses de classe. Resgatar o valor da linguagem simbólica parece ser crucial no questionamento do absolutismo despótico em que incide, às vezes, a linguagem dogmática.

\footnotetext{
${ }^{38}$ Fitzmeyer, A Biblia na Igreja, 62.

${ }^{39}$ Geffré, Como fazer teologia hoje: hermenêutica teológica, 18.

${ }^{40}$ Cardoso, "O futuro do presente da leitura biblica latino-americana”, 148.
} 
Seria em vão qualquer esforço por uma formaçấo teológica decolonial que não levasse em consideração o modo de compreender a Bíblia e a Palavra de Deus, a sua interpretação e aplicação. "A Bíblia é a história de um povo que foi humilhado e oprimido durante séculos, e continua sendo. É a história de um Deus que não aceita essa opressão" "41. Os empobrecidos do mundo todo estão se identificando com esse povo porque "é a sua própria história, a história de suas esperanças e frustraçôes, a história de sua tenacidade e perseverança"

Uma teologia decolonial não se sustentaria sobre uma compreensão bíblica colonizadora. Os tratados teológicos não teriam sentido. Quem almeja trilhar o caminho da teologia decolonial precisa ter consciência que não se faz tal teologia sem uma leitura da Bíblia fundamentalmente decolonial.

\section{Conclusão}

É um desafio pensar a teologia cristã em diálogo com o pensamento decolonial e suas implicaçôes para a formação teológica. Quem se aventura por este caminho incipiente é tentado a cair em generalizações e inconsistências teóricas próprias das novas formulaçóes. Além de práticas pastorais também pouco refletidas. $\mathrm{O}$ caminho adotado nesse artigo aponta para etapas necessárias e correlacionadas rumo a uma formação teológica decolonial consciente da sua inconclusividade.

Desinstalar, decolonizar e libertar são palavras próximas. Elas indicam as condiçôes necessárias para a construção de uma teologia na perspectiva decolonial. Sem tais disposiçôes seria impossível a constatação da importância de uma intelecção da fé pensada e feita na América Latina. Temos sede de um quefazer teológico autóctone. Teologia com a marca da nossa gente; entranhada na nossa história e possibilitadora de novas nuances sobre o divino.

Não nos aproximamos do pensamento decolonial de forma acrítica. Reconhecemos as suas limitaçôes e temos consciência de como alguns dos seus teóricos caem na fase da pura negação de todo conhecimento já adquirido. O importante não é negar, mas discernir o processo de colonização epistêmica e propor caminhos de libertação e reconhecimento dos saberes que foram subalternizados.

Acreditamos que o pensamento decolonial é uma chave de leitura importante para potencializar a perspectiva libertadora de teologias na América Latina como a teologia da libertação, a teologia da missão integral e a teologia pentecostal. Estas três teologias, cada uma a seu modo, abraça dentro de si um leque de possibilidades e

\footnotetext{
${ }^{41}$ Comblin, Introdução geral ao Comentário Bíblico: leitura da Bíblia na perspectiva dos pobres, 8 .

${ }^{42}$ Ibíd.
} 
novidades para uma teologia efetivamente decolonial. Transitar entre as tradições que acolhem essas teologias e deixar ser interpelado por elas é fundamental para o teólogo e a teóloga que queira se debruçar sobre a teologia pública intercultural.

Diferente do Norte, o Sul global vive na atualidade uma redescoberta pelo sagrado e novas formas religiosas. Somos desafiados a uma nova formação teológica como espaço para o reconhecimento das diferenças e acolhimento do outro. A tradição e o dogma não são barreiras para a novidade teológica como afirmam, equivocadamente, alguns setores do pensamento decolonial.

A verdadeira tradição é um processo vivo, dinâmico e criativo. Além do enraizamento numa determinada confissão religiosa, indispensável para o diálogo interfét ${ }^{43}$, a tradição possibilita construir o texto bíblico, conservando-o, atualizando-o criativamente através de novas releituras. $\mathrm{O}$ dogma também é dinâmico e vivo. Ele permite que a substância visada passe por formulaçôes culturais - uma mediação necessária para formulaçôes doutrinárias e crenças pertinentes ao mundo contemporâneo.

O tradicionalismo e o dogmatismo, posturas extremistas, é que são pedras de tropeço para a teologia decolonial. Eles cristalizam e mumificam as expressóes de fé e inviabilizam diálogos e contextualizaçôes. Um cristianismo pautado nestes extremos é instrumento de colonização, afirmam os teóricos do pensamento decolonial. Temos o desafio de resgatar a essência libertadora do seguimento de Cristo e denunciar todas as formas de institucionalização da fé na propagação de uma teologia viva, criativa, inconclusa e fiel ao anúncio das boas novas do Reino de Deus.

\section{Bibliografia}

Ballestrin, Luciana. "América Latina e o giro decolonial". Revista brasileira de ciência política 11 (2013): 89-117.

Brighenti, Agenor. "Natureza, lugar e função da teologia: inovaçôes da teologia latinoamericana". In: Espiritualidade e dinâmicas sociais: memória - prospectivas, organizado por Roberlei Panasiewics e Jaldemir Vitório, 163-184. São Paulo: Paulinas-Sociedade de Teologia e Ciências da Religião, Soter, 2014.

. "Teologia e pluralismo religioso: questôes metodológicas". In Por uma teologia planetária, organizado por José Mariá Vigil, 81-92. Sáo Paulo: Paulinas, 2011.

Cardoso, Nancy. "O futuro do presente da leitura biblica latino-americana". Voices of South: Theological Journal of EATWOT 4 (2014): 147-170.

\footnotetext{
${ }^{43}$ Pui-Lan, Globalização, gênero e construção da paz: o futuro do diálogo interfé, 25.
} 
Comblin, José. Introdução geral ao Comentário Bíblico: leitura da bíblia na perspectiva dos pobres. Petrópolis: Vozes, 1985.

Cunha, Carlos. Hermenêutica biblica libertadora: encontros entre católicos e pentecostais. São Paulo: Garimpo, 2016.

- "Teologia pública e o conceito de 'fronteira' no pensamento de Paul Tillich". Revista atualidade teológica 40 (2012): 109-119.

Dussel, Enrique. "Descolonização epistemológica da teologia". Concilium 350 (2013): 19-30.

Fitzmyer, Joseph. A Bíblia na Igreja. São Paulo: Loyola, 1997.

Fornet-Betancourt, Raúl. "La interculturalidad a prueba". Universidad Centroamericana José Simeón Cañas, UCA, http://www.uca.edu.sv/filosofia/admin/ files/1210106845.pdf (consultado em 28 de março de 2017).

Freire, Paulo. Ação cultural para a liberdade (5a ed.). Rio de Janeiro: Paz e Terra, 1981. . Pedagogia do oprimido (47. ed.). Rio de Janeiro: Paz e Terra, 2005.

Geffré, Claude. Como fazer teologia hoje: hermenêutica teológica. São Paulo: Paulinas, 1989.

Grosfoguel, Ramón. "Para decolonizar os estudos de economia política e os estudos pós-coloniais: transmodernidade, pensamento de fronteira e colonialidade global". Revista critica de ciências sociais 80 (2008): 115-147.

Gutiérrez, Gustavo. Teologia da libertação: perspectivas. São Paulo: Loyola, 2000.

Jacobsen, Eneida. "Modelos de teologia pública". In Teologia pública em debate, organizado por Ronaldo Cavalcante e Rudolf von Sinner, 53-70. São Leopoldo: Sinodal, 2011.

Löwy, Michael. O que écristianismo da libertação? Religião e política na América Latina. São Paulo: Fundação Perceu Abramo: Expressão Popular, 2016.

Mignolo, Walter. "Desobediência epistêmica: a opção descolonial e o significado de identidade em política". Cadernos de letras da UFF. Dossiê: literatura, lingua e identidade 34 (2008): 305.

. Histórias locais/Projetos globais: colonialidade, saberes subalternos e pensamento liminar. Belo Horizonte: UFMG, 2003.

. La idea de América Latina. La herida colonialy la opción decolonial. Barcelona: Gedisa, 2007. 
Palermo, Zulma; e Pablo Quintero (coords.). Aníbal Quijano: textos de fundación. Buenos Aires: Editorial: Ediciones del Signo, 2016.

Panotto, Nicolás. "Decolonizar la educación teológica: hacia una ecologia de saberes teológicos en América Latina”. Academia, http://www.academia.edu/27110864/ Decolonizar_la_educaci\%C3\%B3n_teol\%C3\%B3gica_hacia_una_ ecolog\%C3\%ADa_de_saberes_teol\%C3\%B3gicos_en_Am\%C3\%A9rica_Latina (consultado em 28 de março de 2017).

Passos, Décio. "A construção do conhecimento legítimo: percursos e desafios para a teologia pública no Brasil”. Estudos de religião 41 (2011): 57-76.

Pui-Lan, Kwok. Globalização, gênero e construção da paz: o futuro do diálogo interfé. São Paulo: Paulus, 2015.

Quijano, Aníbal. "Colonialidad del poder y clasificación social”. Clacso, http://biblioteca.clacso.edu.ar/clacso/se/20140506032333/eje1-7.pdf (consultado em 21 de março de 2017).

Santos, Boaventura de Sousa. "Os direitos humanos na zona de contacto entre globalizaçôes rivais”. Cronos 1 (2007): 23-40. . Se Deus fosse um ativista dos direitos humanos (2. ed.). São Paulo: Cortez, 2014.

Segundo, Juan Luis. Libertação da teologia. São Paulo: Loyola, 1978.

Tamayo, Juan José. Teologias del Sur: el giro descolonizador. Madrid: Trotta, 2017. . "Teologia para outro mundo é possível”. In Teologia para outro mundo possivel, organizado por Luiz Carlos Susin, 437-453. São Paulo: Paulinas, 2006.

Tillich, Paul. Teologia sistemática (5. a ed. rev.). São Leopoldo: Sinodal, 2005.

Vigil, José Mariá (org.). Por uma teologia planetária. São Paulo: Paulinas, 2011. 